\title{
Dimensions of Changeability of Futuristic Organizations: Need of Organizations in Change Environment
}

\author{
Najme Jalalian, Masoud Gramipour \\ Payamenoor \\ Iran \\ n.j.manager@gmail.com
}

\begin{abstract}
Rapidity of changes and related complexities has caused organizations to be changeability in all aspects. In order to think about future and take necessary actions, it is needed to create suitable sub-structures and basics by which the organizations are encouraged to have acceptable changeability against future complexities. This is to say that organizations move toward the future on the basis of two main sub structures including "agility" and "multi-faces". This study includes qualitative and quantitative parts. In qualitative part, we focus on the investigation of terms "agility" and "multi-faces". As the two dimensions of organizational changeability for moving toward a changeable future. On the other hand, in quantitative part, a questionnaire has been prepared for examining the relationship between the two variables in governmental universities of Yazd province at AMOS space. The results of qualitative part show that organizational experts argue that futuristic organizations should be agile and multi - faced in order to move rapidly. In this regard, the factors needed for changing dimensions include multiple strategies and goals, dynamic capabilities and multidimensional structures. Moreover, the factors needed for achieving agility include flexibility, learning on the base of mistake, time and tempo, the ability of reconfigurable and the ability of recognizing and solving problems. In quantitative part, the reliability of the questions was confirmed by use of Cronbach's \pm up to $\% 90$. Moreover, all hypothesis were confirmed by use of confirmed factor analysis model $(P>.5)$.
\end{abstract}

Keywords: Changeability, Agility, Multi-face, Futuristic Organization

Received: 4 November 2017, Revised 11 December 2017, Accepted 19 December 2017

DOI: $10.6025 / \mathrm{jdp} / 2018 / 8 / 2 / 51-62$

(C) 2018 DLINE. All Rights Reserved

\section{Introduction}

A well-defined corporate strategy will assist organization to prepare itself to manage dynamism in the business world [1] due to changes caused by uncertainties such as shift in technology innovation and economic power change to Asia, greater economic 
of scale in technology, consumer marketing domination, breakthrough technologies, high adoption of innovation, major IT disaster, high economic growth, immigration backlash, corporate social responsibilities, monetary stability, trade blocks/regulation, terrorist attack, natural disasters, global warming, green technology and borderless world [2]. Therefore, all future organizations should always be able to meet such changes for the purpose of being successful in modern changeable world [3]. It is argued by Everaert (2000) that "future" means "change"[4].

It has been recognized that although organizations, specially, futuristic ones, predict probable events, they are always faced with unpredictable changes when moving toward an obscure future. Such changes, called tsunami, are radically happening nowadays. In comparison to 20 years ago, organizations are rapidly developing. Global markets, competition means that strategies, new products, processes and organizational structures will not be durable in future [5]. Klemke \& Nyhuis (2009) argue that future organizations need to focus on enough resources and potentials in order to react to such unpredictable changes [6].

Investigating the terms "organization" and "future", Hesselbein et al (2000) concluded that [7]: (1) Organizations should change in order to be stable in a changeable environmental and (2) "future" means a determined time limit during which such changes should be happened.

It is not important in what organization we are employed, but it is important to what extent we can be able to resist against probable changes. The ability of improving such capability is regarded as the main characteristic of futuristic organizations. The importance of organizational changes was discussed by Alvin Toffler for the first time in his "Future Shock" book. He has presented a picture from future organizations having characteristics such as dynamism, innovation and learning ability. Future organizations are organized for being innovative and thoughtful. Indeed, economists call it "Creative destruction" [8].

Therefore, most of scholars believe that futuristic organizations should be changeability in future and adapt to probable changes. The future organizations are more changeable and dynamic in comparison with the modern ones [9]. Champy (2000) argues that future - oriented organizations should be stable and careful during multilateral changes [10]. Future - directed organization needs environmental movement, compatibility and transformation. Such an organization not only doesn't regard "change" as a threat, but also looks for suitable changes continually [11].

Because some changes happen rapidly, organizations need performance - oriented procedures in order to be successful, permanently. Therefore, future organizations should be nimble and multi - dimension to be able to increase their changeability against changes. This article examines the dimensions and elements of organizational changeability for the purpose of confronting future changes. The main question to which we have faced is: "what are the characteristics of future - directed organization for having enough flexibility against future changes?"

\section{Research Background and Theoretical Bases}

Evidences show that many scholars have argued that the ability of future - directed organizations for moving towards changes and achieving enough capability is based on some elements including changeability, reengineering, dynamic, speed of action, flexibility, agility and multi dimensionality. From the above mentioned, it becomes clear that change complexity may be happened every moment. Therefore, organizations be obliged to move nimbly. Having high action speed and multiple strategies causes the organization to be dynamic and flexible when encountering future uncertainties and ambiguities. Therefore, organizations should regard speed and carefulness as the two basic elements for encountering future changes [10]. Moreover, they must increase their ability by compiling multiple objectives, resources, structures and strategies.

Futuristic organization should be nimble, careful and powerful in order to be able to encounter with future multiple changes [10]. Several models have been presented futuristic organizations and their structure.

In this regard, the structural model of answering environment [12], Phenotype organizational structure model [13], Chameleon organization model [11] and reconfigurable organization model [14] (Galbraith, 2000) are the basic models by which the future multi-dimensional and rapid changes well be answered. Such models have been presented by new designing bases [15] and new factors related to organizational success [16] including speed, flexibility, versatility, innovation and bases of complexity science

\begin{tabular}{lllll}
\hline 52 & Journal of Data Processing Volume 8 & Number 2 June 2018 \\
\hline
\end{tabular}




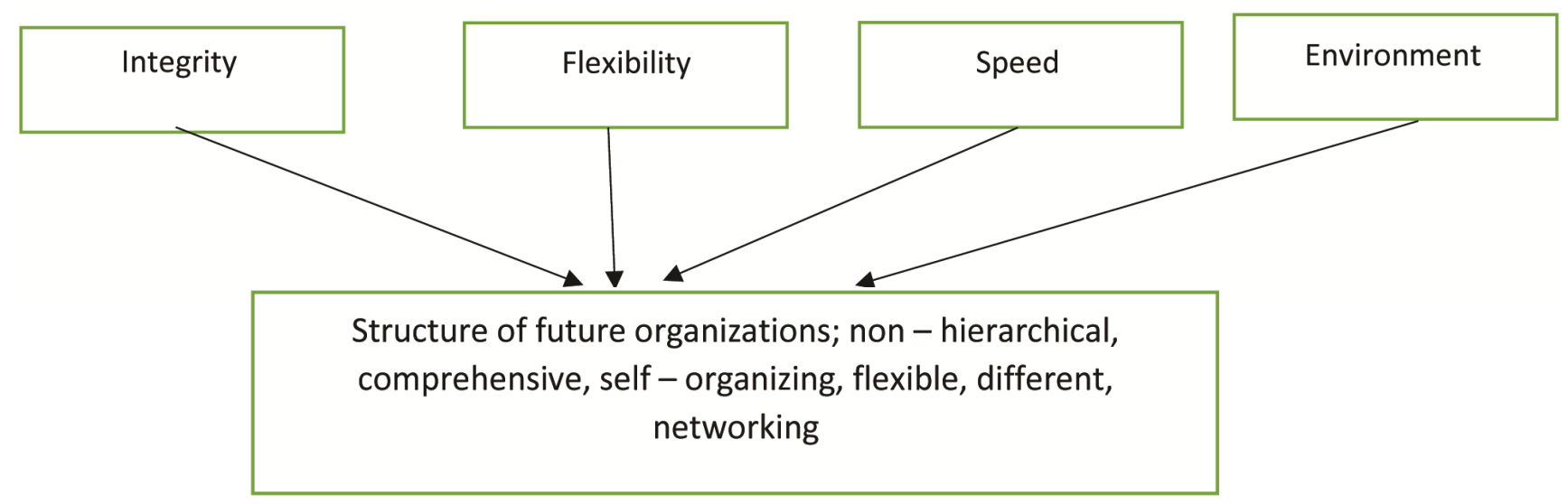

Figure 1. The influence of organizational success factors on designing the structure of dynamic and complex environment

(to be nonlinear, non - hierarchical, comprehensive, self-organizing, flexible, different and networking).

From the above mentioned, the complex and uncertain future organizational structures and models should be changed rapidly. Therefore, as mentioned before, it is necessary the current models to be agile and multi-face.

\subsection{Agility}

This is to say that rapidity of action against the changes is one of the main aspects of future radical changes, because there are issues to which organizations are faced [17]. In such condition, it is impossible to manage organizations traditionally. In so doing, it is necessary to achieve organizational agility [8]. In current condition, agility means to react to the variable and unpredictable environment and to use changes as the opportunities for developing organizations: The term "nimble" means to be able to move rapidly and think impetuously. "Agility" takes root of nimble production used by producers as a successful procedure for increasing their performance. Organizations are not threaten by being unable to future recognition when they can be changed nimbly [7]. Therefore, "agility" is one of the main capabilities of future organization [19] and its success [7]. Yusuf et al. (1999) proposed that agility is successful application of competitive based such as speed, flexibility, innovation, and quality by the means of the integration of reconfigurable resources and best practices of knowledge-rich environment to provide customer-driven products and services in a fast changing environment [20], by speed we mean the ability of organization to recognize new products, new employment contracts, new commercial performance and rapid entrance to future markets. Such capability is performed by managers as follows:

- Problem management (recognizing and solving problems rapidly);

- Preparing suitable tempo and timing for organizational changed;

- Preparing suitable field for reconfigurable happened changes;

- Taking lessons from mistakes and eradicating organizational viruses;

- Eliminating dependent obstacles, networking and increasing cooperation's;

- Being flexible.

\subsubsection{Problem Management (Recognizing and Solving Problems Rapidly)}

Problem management is one of the main elements of public relations, public issues ad futuristic procedures [21]. For the first time, the term "problem management" was presented by Chase (the manager of public relations of companies such as General Mils2 and former economy minister of US) in 1976. In his book "problem management future capitals", Chase (1984) has presented some basic definitions. He states: "There is no significant problem that we decide about it. Moreover, procedures are predictable changes which appear before problems" [22]. Chase (1981) points out that weakness means to defend yesterday instead of managing changes. He also asks the futuristic mangers to manage problems instead of being defender [23]. Cutlip et 
"problems management includes two main elements. The first one consists of "rapid recognition of problem and its influences on the organization". The second one includes "rapid presentation of a strategic response for decreasing related consequences and investing capital" [24].

\subsubsection{Recognizing and Solving Problems}

One of the main characteristics of organizational agility is the recognition of problems [25]. Moreover, rapid solution of unpredictable problems happens at the chain of creating agility [26]. Therefore, a futuristic organization should be able to achieve agility [21]. Environmental cleverness and prediction helps the organization to recognize problems rapidly.

\subsubsection{Preparing Suitable Tempo and Timing}

In reality, agility is proposed for managing organizational changes and transformations. Agility is referred to react to an unpredictable environmental changes. The use of such changes is regarded as the opportunity for developing organization. In a nimble provision chain, characterized by environmental transformations, organization is faced uncertainty. Moreover, it is expected that organization to be able to react rapidly in such opportunity [27]. In this regard, the two factors tempo and timing are of great importance [4]. "Tempo" means the speed of performing change and "timing" means the time of performing change. Tempo may improve organizational performance during managing organizations programs. The term "tempo" means to reserve progressive condition and response changes including change in client's needs, change in comparative world, change in rules, global changes, social changes and political changes. The modern organizations use two elements "tempo" and "timing" in their policies in addition to designing future. Timing is as a two - edged sword. From timing perspective, the following question should be answered: "when should we do the work?" From Tempo perspective, it should be said that "what speed should be mentioned during the work?" In other words, these factors (time of performing and speed of performing) should be noticed when a program is regulated for improving organizational performance.

\subsubsection{Networking (Openness Resource)}

Organizational symbols have currently changed to network structures: in this regard, the related criterions include demanding groups, horizontal cooperation procedures and false systems [28] It is necessary the future organizations to have unlimited capability, because they can make decisions rapidly by taking off boundaries [29]. Moreover, they can be freely in communication with each other. Galbraith (2000) argues that organizations can be easily changed when their structures are suitable [14]. Furthermore, one of the main capabilities of the organization is the creation of internal networks by which the changes can be rapidly happened, the dynamic relationship can be created and accurate program can be presented [4]. The future organizations should improve the ability of knowledge networking [30] and promotion of informal networks in order to preserve suitable reaction against changes and needed capacity [31]. Development of networked world is one of the main tools of future-directed organizations for reacting changes and creating agility [32, 33, 34,35]. In current decades, futuristic leaders lead their organizations toward network living [36]. The use of such informational innovations (especially market - based soft wares) increases the ability of organizations for having network structure. Such software community is the new paradigm of work division in the form of network [37], created by networking of addresses.

\subsubsection{Learning from Mistakes}

Future organization should consider each error as an opportunity for learning and avoid from repeating it. Agility is based on the organization's commitment for learning a lesson from current events and acting to them [9]. Such actions decrease the errors and increase the rapidity of learning in an organization [38]. A future organization improve its changeability level by increasing of learning ability [39]. Quickness of learning is achieved when the new concepts are distributed throughout the organization. The futuristic organization should take lessons from its performances and competitors. Authors believe that the main advantage of future organizations are their rapidity of learning. Organizational innovation is developed by considering rapid learning as one of the main elements of an organization [29]. (Ulrich, 2000). Therefore, future organizations need leaders who are inquisitive about various subjects and make good progress synchronize with new challenges [40].

\subsubsection{The Ability of Reconfigurable}

In order to be synchronized with changes, it is necessary the organization to be able to prepare balanced organizational arrangement by which the structures and processes are changed. Organization should change its framework and rearrange its internal elements. In so doing, it is necessary the organization to have the ability of reconfigurable internal aspects. The most important part of future organization should operate as a mirror for external environment of trade [41], so that it can be able to create a new system by use of available data. In this regard, processes will be appeared, structures of organizational

\begin{tabular}{lllll}
\hline 54 & Journal of Data Processing Volume 8 & Number 2 June 2018 \\
\hline
\end{tabular}


communications will be interchanged, sub structures of new technology will be required and the employees' behavior well be changed [10].

\subsubsection{Flexibility}

Today, it is almost impossible to find a successful organization which acts based on a closed system. The successful organizations should use an open system and adopt themselves to the environmental changes [27]. The future organizations should make themselves flexible against complexed and multiple changes in order to be succeed [42]. Such capability leads to the increase of organizational flexibility against future changes and ambiguities [14]. Handy (2009) argues that future organization is the symbol of new occasions and the changeable combination of particles and waves [43]. In comparison to the current organizations, futuristic ones are more dynamic and flexible [9]. Such an organization is adoptable to new conditions [32]. There are several kinds of flexibility. Organizational flexibility new by which we can emphasize creatively on marketing and finding technologies and opportunities. Therefore, flexibility reveals the degree of capacity of organization for changing and attracting new environmental ideas and technologies [12]. Flexibility and rearrangement of organizations against future changes develop organizational dimensions, multiple environmental strategies, multi-dimensional structures and dynamic capabilities.

\subsection{Multi - faces}

As there are several environmental factors, the modern environments are very complex. Moreover, such environments are not stable because of rapid technological development. In such stormy environments, it is almost difficult to predict future changes. Moreover, technology is rapidly changing and persons are competing with each other. Therefore, "stability" means to die in such environments [44].

It is needed the organizations to find a multiple anisotropic path in order to combat various environmental compounds [45]. These compounds include:

1. The compounds related to environmental agitation;

2. The compounds related to organizational changes;

How can we manage such infinite multiplicity? In so doing, it is necessary to have a systematic framework. As the future organizations will face up to various compounds and environments, they should follow a policy by which the complexities resulted from such multiplicity can be made clear [45]. These complexities are resulted from available multiplicity. Moreover, they have also influence on it. Therefore, the relationship between those factors is inseparable as the relationship between the two sides of a coin. These two factors impose some obligations on the organization. One of these obligations is multidimensionality of future organization against environmental complexities and advances [46]. The future organizations should be flexible against multidimensionality and have high tolerance [40]. They should strengthen their relations, objectives, resources and multiple capabilities. This is to say that there is no unique knowledge which can be included all patterns and policies in multi-dimensional modern world. Therefore, it is necessary to move from one - dimensional environment to multi-dimensional one [32] in order to create multiple models [3].

As mentioned before, organizations have differently appeared in reply to current environmental complexities [47]. Therefore, an organization can become apparent in various faces just as a person [47]. In this regard, the characteristics by which an organization can have various faces are of great importance. These characteristics include multiple strategies and goals, multidimensional structure and dynamic capabilities.

\subsubsection{Multiple Strategies and Goals}

Futuristic organizations have developed various strategies and goals which are based on a strategic architecture [48]. They move usually from one - dimensional into multidimensional space included different ideas and viewpoints for solving problems. Such organizations present various attitudes toward future in order to empower themselves against environmental uncertainties. A futuristic leader knows that an issue may include several aspects which should be mentioned during making decisions [49]. Creating multi - aspect attitudes toward future and multi - dimensional viewpoints and predictions [50], a futuristic organization chooses various strategies and goals and changes them continually [48].

\subsubsection{Multidimensional Prediction}

It is important to say that prediction of various issues is difficult, specially, the issues related to the social and cultural 
tendencies. In other words, we should not emphasize on the certainty of prediction, but we should focus on various possibilities regarding all uncertainties and complexities related to the future. As the natural and human phenomena are not based on linear process, it is necessary to consider various conditions in which such phenomena are happened [51, 52]. Due to this new paradigm, it is argued that there are several futures which may be happened separately. This is a main principle relative to futuristic income. In futuristic paradigm, it is possible to think about probable future. Therefore, this is to say that there are four kinds of future [53]:

1. Possible future: It includes all possible circumstances which may be created in future. It is not important how they are created.

2. Plausible future: It includes all futures which can be created on the basis of modern knowledge.

3. Probable future: It refers to the futures that will happen probably (e.g.: the current procedures).

4. Preferable or desirable future: This kind of future takes root of value judgments. Therefore, such futures are mental not actual.

\subsubsection{Multi-dimensional Structures}

Many evidences show that there is only one kind of organizational structure. It is not true, because an organization is not a definite phenomenon; specially, about future organization. The one - dimensional structures are insufficient and restricting for living in complexed and changeable environment. From the above mentioned, which structure is suitable? The number and diversity of structural units is under the influence of environmental factors. Moreover, the structure of organizations is influenced by their duties and goals [54]. Therefore, restructuring is one of the main challenges to which the futuristic organizations are faced [55]. Future organization has a strategic architecture. In this structure, there are several ways to divide power on the basis of strategy so that both trade and geographic conditions can be observed [56]. Therefore, futuristic organization uses various methods in its structure for cooperating and managing the employees by which it can achieve multiple goals [48]. In multidimensional structures, the work advance is based on the cooperation of various departments. Such organization needs some structural units which not only tend to do economic activities, but also to respond demands of clients, work force, activities and leaders.

\subsubsection{Dynamic Capabilities}

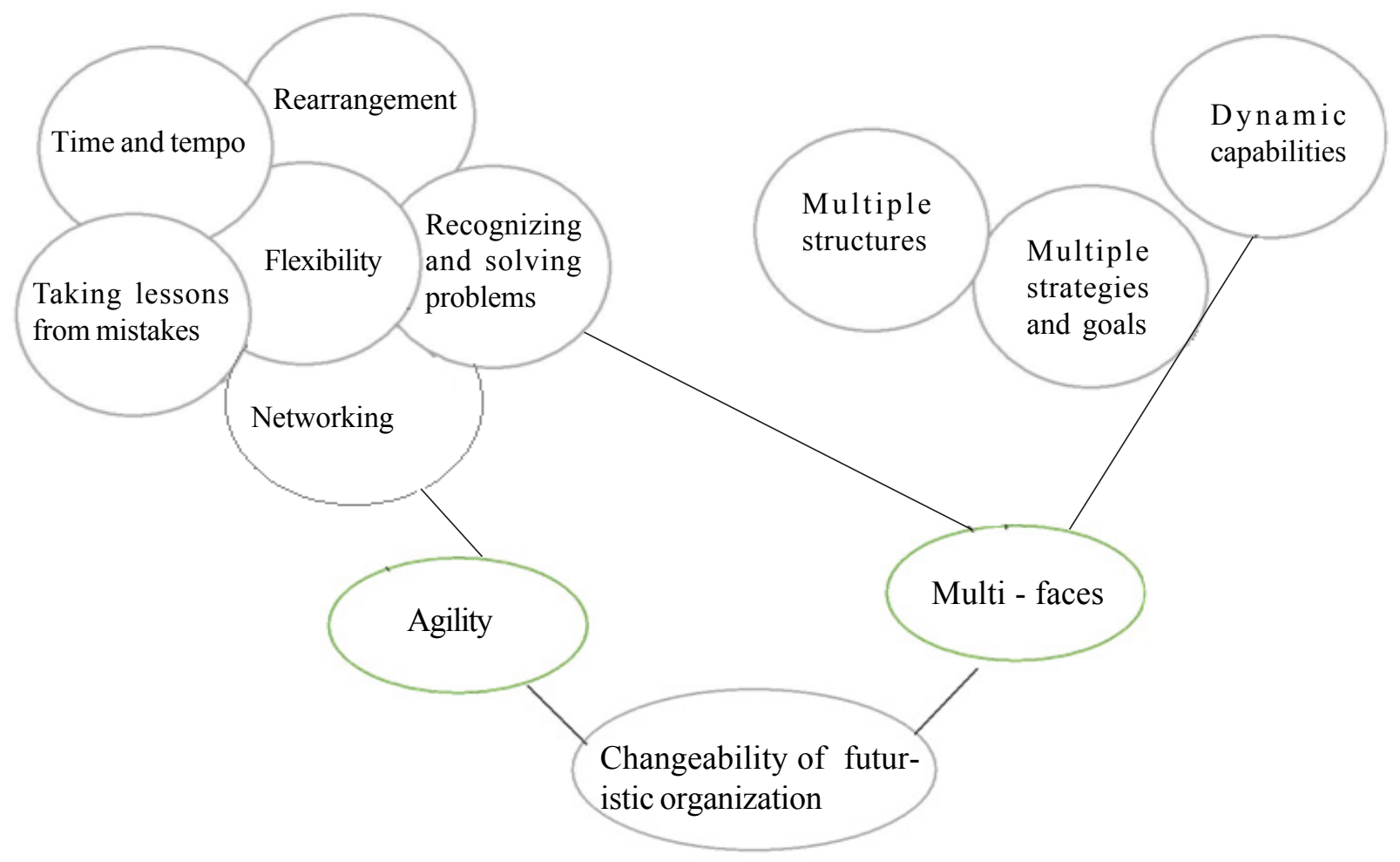

Figure 2. Changeability of futuristic organization 
Following winter (2003), a capability is a collection of organizational routines that enable a firm to perform some set of tasks on a repeatable or consistent basis [56]. The term know-how and capabilities will be used interchangeability [57]. Stacey (2003) argues that dynamic capabilities are referred to the ability of organization to integrate, create and manage internal/external capabilities in order to confront rapid environmental changes [52]. In doing so, the organization should renovate its valuable resources to stabilize its comparative preference in external environmental change conditions. Dynamic capabilities enable the organization to impact on continual changes. In reality, there is a relationship between strategy and resources such as skilled human force, multiple investments, multiple markets and achievable information [58].

\section{Research Methodology}

In order to examine validity of the variables, 3309 employees of governmental universities of Yazd province were selected as the statistical population. A questionnaire designed by researcher was distributed to the sample included 500 employees and faculty members of the universities. Validity of the questionnaire was confirmed because $\alpha>\% 90$ (table 1). Regarding the highest variance (\%74) of $\mathrm{t}$ - pretest and statistical population; Included 2309 employees and faculty members, more than 400 persons were selected as the sample by use of Cocharan's formula. 414 out of 500 questionnaires distributed to the employees and faculty members were received. Demographic information related to the questionnaire has been shown in table 2 .

\begin{tabular}{|c|c|c|c|c|}
\hline Dimension & $\begin{array}{l}\text { Cronba } \\
\text { ch's } \alpha\end{array}$ & Elements & $\begin{array}{l}\text { Number of } \\
\text { questions }\end{array}$ & $\begin{array}{l}\text { Cronbach's } \\
\alpha\end{array}$ \\
\hline \multirow[t]{6}{*}{ Agility } & \multirow[t]{6}{*}{.95} & $\begin{array}{l}\text { The ability of recognizing and solving } \\
\text { problem }\end{array}$ & 4 & .84 \\
\hline & & Time and tempo & 7 & .90 \\
\hline & & Taking lessons from mistakes & 5 & .90 \\
\hline & & The ability of re arrangement & 5 & .81 \\
\hline & & Networking & 6 & .83 \\
\hline & & Flexibility & 4 & .91 \\
\hline \multirow[t]{3}{*}{ Multi-faces } & \multirow[t]{3}{*}{.89} & Multiple strategies and goals & 4 & .90 \\
\hline & & Dynamic capabilities & 4 & .76 \\
\hline & & Multidimensional structures & 4 & .70 \\
\hline
\end{tabular}

Table 1. Cronbach's \pm and number of questions

\begin{tabular}{|c|c|c|c|c|c|c|c|}
\hline \multicolumn{2}{|l|}{ Variables } & \multirow{2}{*}{\begin{tabular}{|l|} 
Frequency \\
183 \\
\end{tabular}} & \multirow{2}{*}{$\begin{array}{l}\text { percent } \\
44.2\end{array}$} & \multicolumn{2}{|l|}{ Variables } & \multirow{2}{*}{\begin{tabular}{|l|} 
Frequency \\
69
\end{tabular}} & \multirow[b]{2}{*}{16.7} \\
\hline Sex & Male & & & \multirow[t]{2}{*}{ Education } & M.A & & \\
\hline & Female & 231 & 55.3 & & PH.D & 174 & 42 \\
\hline \multirow[t]{3}{*}{ Place } & $\begin{array}{l}\text { Open } \\
\text { university }\end{array}$ & 102 & 24.6 & \multirow[t]{2}{*}{ Age } & $20-30$ & 38 & 9.2 \\
\hline & Yazd & 156 & 37.7 & & $31-40$ & 226 & 54.6 \\
\hline & $\begin{array}{l}\text { Sh.Sadooghi } \\
\text { medical } \\
\text { science }\end{array}$ & 156 & 37.7 & & $41-50$ & 121 & 29.2 \\
\hline \multirow[t]{3}{*}{ education } & Diploma & 1 & .2 & \multirow[t]{3}{*}{ Position } & $51-60$ & 28 & 6.8 \\
\hline & Associated & 39 & 9.4 & & $\begin{array}{l}\text { Faculty } \\
\text { member }\end{array}$ & 215 & 51.9 \\
\hline & B.A & 123 & 29.7 & & Employee & \begin{tabular}{|l|}
199 \\
\end{tabular} & 48.1 \\
\hline
\end{tabular}

Table 2. Demographic information 


\section{Data Analysis}

As mentioned before, the confirmed factor analysis method was used to confirm elements. The result achieved by Amos software is as below (figure 3 ).

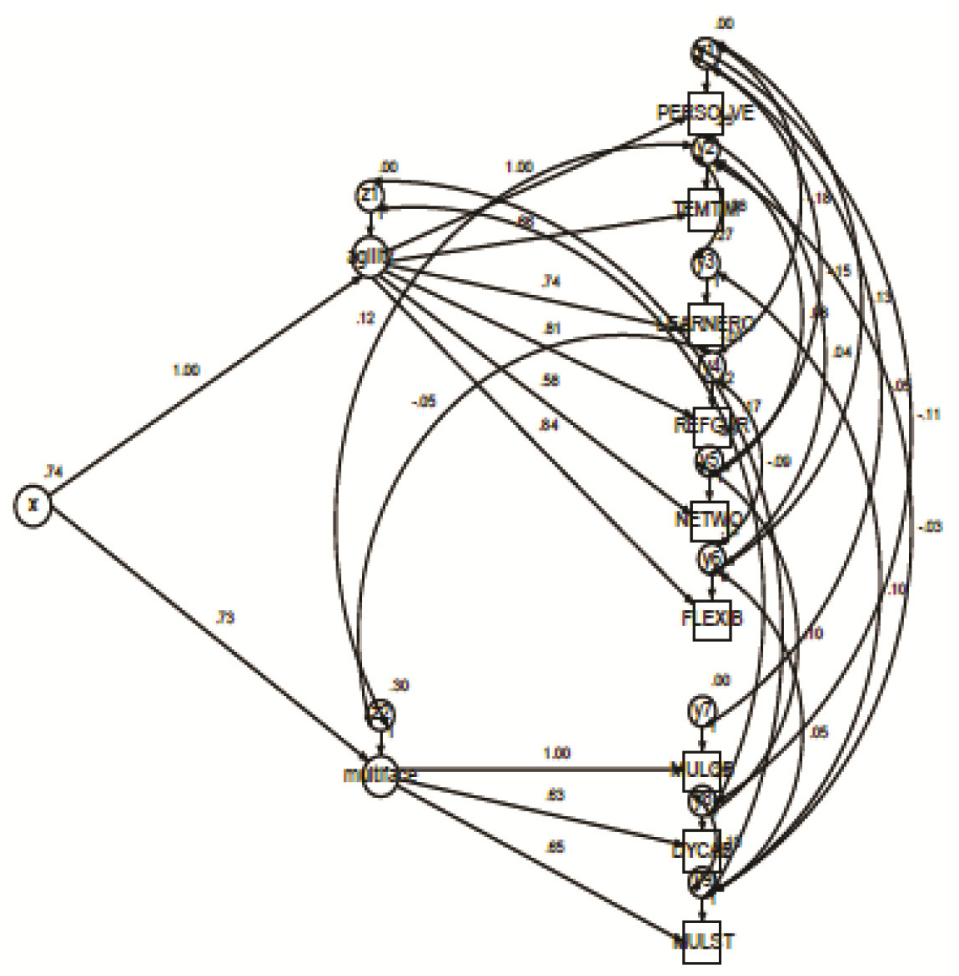

Figure 3. Results of Amos software

The results of first step (dimensions and futuristic organization): Due to gathered data (table 3), it becomes clear that there is a meaningful positive relationship between variables flexibility, agility and multi-faces.

\begin{tabular}{|l|l|l|l|l|l|l|}
\hline Title & $\begin{array}{l}\text { Raw score of } \\
\text { factor } \\
\text { loading }\end{array}$ & $\begin{array}{l}\text { Standardize } \\
\text { value }\end{array}$ & $\begin{array}{l}\text { Standard } \\
\text { estimated } \\
\text { value }\end{array}$ & T - value & $\mathrm{P}-$ & R2 \\
\hline Multi faces & .733 & .755 & .036 & 20.551 & $\mathrm{P}<.01$ & .57 \\
\hline Agility & 1.000 & 1.000 & $*$ & $*$ & $\mathrm{P}<.01$ & 1.000 \\
\hline
\end{tabular}

Table 3. Factor loading at first (flexibility of futuristic organization and elements)

As shown in table 4, there is a meaningful and positive relationship between all dimensions and their elements.

Finally, as seen in table 5, the hierarchical confirmed factor analysis model is acceptable.

\section{Result and Discussion}

The statistical results show that the main elements of multi-faces factor in futuristic organization include multiple strategies and goals, dynamic capability and multidimensional structure. Moreover, the main criteria related to agility factor include the ability of rearrangement, flexibility, learning from mistakes, time and tempo, the ability of problem recognizing and solving and networking. Therefore, one of the main elements of futurism is the ability of prevailing over difficulties related to changeability.

\begin{tabular}{lllll}
\hline 58 & Journal of Data Processing & Volume 8 & Number 2 & June \\
\hline
\end{tabular}




\begin{tabular}{|l|l|l|l|l|l|l|l|l|}
\hline & Factor & Codes & $\begin{array}{l}\text { Raw } \\
\text { score of } \\
\text { factor } \\
\text { loading }\end{array}$ & $\begin{array}{l}\text { Standardized } \\
\text { value }\end{array}$ & $\begin{array}{l}\text { Standard } \\
\text { estimated } \\
\text { value }\end{array}$ & $\begin{array}{l}\text { T } \\
\text { value }\end{array}$ & $\begin{array}{l}\text { Meaningful } \\
\text { level }\end{array}$ & R2 \\
\hline $\begin{array}{l}\text { Multi } \\
\text { faces }\end{array}$ & $\begin{array}{l}\text { Multiple } \\
\text { strategies } \\
\text { and goals }\end{array}$ & Mulub & $*$ & .758 & $*$ & $*$ & $\mathrm{P}<.01$ & 1.000 \\
\cline { 2 - 9 } & $\begin{array}{l}\text { Dynamic } \\
\text { capabilities }\end{array}$ & Dycab & .634 & .723 & .028 & 22.283 & $\mathrm{P}<.01$ & .523 \\
\cline { 2 - 9 } & $\begin{array}{l}\text { Multiple } \\
\text { structure }\end{array}$ & Mulst & .645 & .692 & .032 & 20.087 & $\mathrm{P}<.01$ & .478 \\
\hline
\end{tabular}

\begin{tabular}{|l|l|l|l|l|l|l|l|l|}
\hline Agility & $\begin{array}{l}\text { The ability of } \\
\text { recognizing } \\
\text { and solving } \\
\text { problem }\end{array}$ & Presolve & $*$ & .754 & $*$ & $*$ & $\mathrm{P}<.01$ & 1.000 \\
\cline { 2 - 9 } & Time and tempo & Tempti & .644 & .769 & .026 & 25.528 & $\mathrm{P}<.01$ & .591 \\
\cline { 2 - 9 } & $\begin{array}{l}\text { Learning from } \\
\text { mistakes }\end{array}$ & Leaner & .742 & .774 & .029 & 25.860 & $\mathrm{P}<.01$ & .599 \\
\cline { 2 - 9 } & $\begin{array}{l}\text { Rearrangement } \\
\text { ability }\end{array}$ & Refgur & .807 & 1.007 & .031 & 25.886 & $\mathrm{P}<.01$ & 1.013 \\
\cline { 2 - 9 } & Networking & Netwo & .577 & .706 & .032 & 17.465 & $\mathrm{P}<.01$ & .489 \\
\cline { 2 - 9 } & Flexibility & flexib & .904 & .904 & .034 & 24.574 & $\mathrm{P}<.01$ & .817 \\
\hline
\end{tabular}

Table 4. Factor loading related to dimensions and elements

\begin{tabular}{|l|l|l|l|}
\hline The title of indicator & Value & Acceptable range & The result of model \\
\hline$\kappa^{2} / \mathrm{df}^{2}$ & 1.9 & $\kappa^{2} / \mathrm{df}^{2}<2$ & Approving the model \\
\hline GFI & .993 & GFI $>9$ & Approving the model \\
\hline RMR & .016 & RMR 0 & Approving the model \\
\hline AGFI & .969 & CFI $>.95$ & Approving the model \\
\hline RMSEA & .025 & RMSEA $<0.09$ & Approving the model \\
\hline NFI & .997 & NFI $>.9$ & Approving the model \\
\hline CFI & .999 & CFI $>.9$ & Approving the model \\
\hline RFI & .988 & RFI $>9$ & Approving the model \\
\hline IFI & .999 & IFI $>9$ & Approving the model \\
\hline
\end{tabular}

Table 5. Indexes of final path model related to flexibility of futuristic organization

The managers should know that the organizations can be preserved against modern radical changes by being flexible and moving toward multiple goals and strategies. 
In order to supply their needs, organizations should feel it is needed to recognize and develop their internal social changes. The needed change is related to the organization s position. In this regard, organization should evaluate current and desirable conditions in order to choose and perform the most suitable strategy. Moreover, the futuristic organizations must be able to [60]:

- Be advised of external environmental dynamisms ( i.e. organizations should emphasis on dynamisms and recognize them dynamically)

- Recognize strong and weak points;

- Create long - term changeable capabilities in future by recognizing current changeable items;

- Create obligatory capability in themselves and be obliged to it;

- Recognize emotional dimension of strategic changes and support persons;

- Make clear both general and particular programs;

- Improve their creativity, knowledge and self-checking in order to achieve unrespectable results;

- Develop changes in order to be able learn continually;

In so doing, organizations should increase their speed and flexibility in addition to their environmental cleverness and futurism. Therefore, the futuristic leaders are usually looking for unpredictable events during their work - life. They manage problems and take lessons from mistakes because they emphasize on multidimensional goals and capabilities in dynamic networks.

\section{References}

[1] Burgelman, R. A., Grove, A. (2007). Let Chaos Reign, then Reign In Chaos - Repeatedly: Managing Strategic Dynamics for Corporate Longevity, Strategic Management Journal, 28. 965-979.

[2] Muthuveloo, R., Ping, T. A. (2014). Swim: Futuristic Framework for Strategic Management Process, American Journal of Applied Sciences, 11 (9) 1703-1713.

[3] Baily, D. (2009). Pioneering the college of future: building AZ we walk. In Hesselbein, F., Goldsmith, M. (2009), The Organization of the Future 2 (Visions, Strategies, and Insights on Managing in a New Era), Waily: Jossey-Bass.

[4] Everaert, P. J. (2000). Emotions, Tempo, and Timing in Managing People. In Hesselbein, F, Goldsmit, M., Beckhard R. (2000). The organization of the future, The Drucker Foundation, Waily: Jossey-Bass.

[5] Santagada, G. (2012). Working with Change Management in the Global Environment, Singapore: International Conference on Management and Education Innovation IPEDR 37. 300-304.

[6] Klemke, T., Nyhuis, P. (2009). Lean Changeability - Evaluation and Design of Lean and Transformable Factories, World Academy of Science, Engineering and Technology, 53. 647- 654I. S. p. 271-350.

[7] Hesselbein, F., Goldsmit, M., Beckhard, R. (2000). The organization of the future, The Drucker Foundation, Waily: JosseyBass.

[8] Koohi, S. (2008). Transformation Management, Tehran: Statistics and Information Technology Office.

[9] Seffrin, J. R. (2000). The Voluntary Health Organization of the Future. . In Hesselbein, F, Goldsmit, M., Beckhard R. (2000). The organization of the future, The Drucker Foundation, Waily: Jossey-Bass.

[10] Champy, J. A. (2000). Preparing for Organizational Change, In: Hesselbein, F., Goldsmith, M. (2009), The Organization of the Future 2 (Visions, Strategies, and Insights on Managing in a New Era), Waily: Jossey-Bass.

[11] Miller, D. (2000). The Future Organization: A Chameleon in All Its Glory. In Hesselbein, F, Goldsmit, M., Beckhard R. (2000). The organization of the future, The Drucker Foundation, Waily: Jossey-Bass.

[12] Stanton, R. R. (1979). Future Organizations: A Model of Structural Response to Organizational Environment, Technological Forecasting and Social Change 15(2) 17-240.

[13] Griffiths L.M., Sambrook S. (2010). Organizational structure for the twenty-first century, Presented at the annual meeting of INFORMS, Austin. 
[14] Galbraith, J. R. (2000). The Reconfigurable Organization. In Hesselbein, F, Goldsmit, M., Beckhard R. (2000). The organization of the future, The Drucker Foundation, Waily: Jossey-Bass.

[15] Rasmus, D. W. (2011). The Design of Organization Next, Sponsored by Cisco, Retrieved from: http://www.cisco.com/en/US/ prod/collateral/ps10680/ps10683/ps10668/C11-657924_design_org_next_WP.pdf

[16] Ashkenas, R., Ulrich, D., Jick, T., Kerr, S. (1955). The boundary less organization breaking the chains of organizational of structure. San Francisco: Jossey base.

[17] Power, D., Sohal, A., Rahman, S. (2001). Critical success factors in agile supply chain management, Intrnational Journal of Physical Distribution \& Logistics management, 31 (4) 247-265.

[18] JafarNejad, A., Shahabi, B. (2007). Organizational agility and nimble production”, Institute of "Ketab - e - Mehraban, Tehran: first edition.

[19] Ulrich, D., Smallwood, N. (2009). Organization Is Not Structure but Capability. In Hesselbein, F., Goldsmith, M. (2009), The Organization of the Future 2(Visions, Strategies, and Insights on Managing in a New Era), Jossey-Bass.

[20] Alzoubi, Haider., A. E., Al-otoum, F. J., Albatainh, Fawwaz, A. K. (2011). Factors associated affecting organization agility on product development. International Journal of Recent Research and Applied Studies, 9 (3) 503-516.

[21] Marx, G. (2006). Future-focused leadership: preparing schools, students, and communities for tomorrow's realities, Association for Supervision and Curriculum Development Alexandria, Virginia USA.

[22] Chase, W. H. (1984). Issue management: Origins of the future. Stamford, CT: Issue Action Publications.

[23] Chase, W. H. (1981). Issues management. In: J. S. Nagelschmidt (Ed.), New York: American Management Association (AMACOM).

[24] Cutlip, S., Center, A., Broom, G. (1994). Effective public relations. Englewood Cliffs, NJ: Prentice-Hall.

[25] Plonka, FE. (1997). Developing a lean and agile work force. International Journal of Human Factors in Manufacturing, 7 (1) 11-20.

[26] Christopher, M., Towill, D. R. (2001), An integrated model for the design of agile supply chains, International Journal of Physical Distribution and Logistics, 31 (4) 235-246.

[27] Sherehiy, B., Karwowski, W., Layer, J. (2007). Areview of enterprise agility: concepts, frameworks, and attributes, Intrnational Journal of Industrial Ergonomics, 37. 445-460.

[28] Marshall S. P. (2000). Creating Sustainable Learning Communities for the Twenty-First Century. In: Hesselbein, F, Goldsmit, M., Beckhard R. (2000). The organization of the future, The Drucker Foundation, Waily: Jossey-Bass.

[29] Ulrich, D. (2000). Organizing Around Capabilities. In Hesselbein, F, Goldsmit, M., Beckhard R. (2000). The organization of the future, The Drucker Foundation, Waily: Jossey-Bass.

[30] Hesselbein, F., Goldsmith, M. (2009). The Organization of the Future 2(Visions, Strategies, and Insights on Managing in a New Era), Waily: Jossey-Bass.

[31] Katzenbach, J. R., Khan, Z. (2010). Leading Outside the Lines, How to Mobilize the Informal Organization, Energize Your Team, and Get Better Results, Jossey Bass Wiley.

[32] McDonald, P. (2011). It's time for management version 2.0: Six forces redefining the future of modern management, Futures, 43. 797-808.

[33] Meister, J. C., Willyerd, K. (2010). The 2020 Workplace: How Innovative Companies Attract, Develop, and Keep Tomorrow's Employees Today [Hardcover], Publisher: Harper Business.

[34] Christopher, M. (2000). The Agile supply chain: Competing in volatile Markets, Industrial Marketing Management, 29. 3744.

[35] Van, H.R. (2001). Epilogue: moving forward with agility, International Journal of physical distribution \& Logistics Management, 31 (4) 289-303.

[36] Feather, F. (2006). Futuristic Leadership A-Z [Paperback], Publisher: Future-Trends.com.

[37] Giuri, a,1,P., Rullani b,2, F., Torrisi, S. (2008). Explaining leadership in virtual teams: The case of open source software, 
Information Economics and Policy, 20. 305-315.

[38] A. C. (1996). Learning from mistakes is easier said than done: Group and organizational influences on the detection and correction of human error, the journal of applied behavioral science, 32 (1) 5-28.

[39] Iain, Somerville., Moroz John Edwin. (2000). New Competencies for a New World. In Hesselbein, F., Goldsmit, M., Beckhard R. (2000). The organization of the future, The Drucker Foundation, Waily: Jossey-Bass.

[40] Clark. (2004), Sustaining Change in Universities: Continuities in Case Studies and Concepts. Berkshire, UK: Open University Press.

[41] Miller, E. D. (2000). Shock Waves from the Communications Revolution. In Hesselbein, F., Goldsmit, M., Beckhard, R. (2000). The organization of the future, The Drucker Foundation, Waily: Jossey-Bass.

[42] Rohrbeck, R. (2010). Corporate Foresight: Towards a Maturity Model for the Future Orientation of a Firm, Heidelberg and New York: Physica-Verlag, Springer Retrieved from: http://futureorientation.net/2010/07/29/what-is-organizational-futureorientation/

[43] Handy Ch. (2009). Revisiting the Concept of the Corporation. In Hesselbein, F., Goldsmith, M. (2009), The Organization of the Future 2(Visions, Strategies, and Insights on Managing in a New Era), Waily: Jossey-Bass.

[44] Slater, R. (2008). New ideas for modern century: Future research basics and methods, (translated by Farah Maleki, Vahid Vahidi Motlagh \& Ibrahimi), Tehran: Research and educational institute of defense industries.

[45] Thomas, R. Roosevelt Jr. (2000). Diversity and Organizations of the Future. In: Hesselbein, F, Goldsmit, M., Beckhard R. (2000). The organization of the future, The Drucker Foundation, Waily: Jossey-Bass.

[46] Galbraith, J., Downey, D., Kates, A. (2002). Designing dynamic organizations: A hands-on guide for leaders at all levels. AMACOM, New York.

[47] Sarlak, M. A. (2011). Organizational faces in 21th century, Tehran, "Marjae Danesh" publication, first edition.

[48] Nadler D. A., Tushman M. L. (1999). The Organization of the Future: Strategic Imperatives and Core Competencies for the 21st Century, Organizational Dynamics, 28 (1) 45-60.

[49] Bennis, W., Goldsmith, J. (2003), From Learning to Lead, 3rd ed, New York: Basic Books.

[50] Mami Zadeh, J. (2008). Management of future organization, Tehran: first edition.

[51] Hajaiani, E. (2011), Future research basics and methods; Tehran; Imam Sadegh University, first edition.

[52] Stacy R. D. (2003). Management of unknown things (the efficient borders between order and disturbance in organization, (translated by Mohsen Ghadami \& Masoud Niazmand), "high institute of management education and research", second edition.

[53] Voros, J. (2001). Reframing environmental scanning: an integral approach, Foresight 3 (6) 533-551.

[54] Platt L.E. (2000). Employee Work-Life Balance: The Competitive Advantage. Hesselbein, F, Goldsmit, M., Beckhard R. (2000). The organization of the future, The Drucker Foundation, Waily: Jossey-Bass.

[55] Drucker, P. (1999). Management challenges, 21th century, (translated by Rezaee Nejad), Tehran, Fara publication, 5th edition.

[56] Winter S.G. (2003). Understanding dynamic capabilities. Strategic management journal, 24, 991-995.

[57] Pisano G. P. (2015). A Normative Theory of Dynamic Capabilities: Connecting Strategy, Know-How, and Competition, Working Paper 16-036, Harvard Business School.

[58] Guttman, H. M. (2009). The new high- performance, horizontal organization. In Hesselbein, F., Goldsmith, M. (2009), The Organization of the Future 2(Visions, Strategies, and Insights on Managing in a New Era), Waily: Jossey-Bass.

[59] Auster, E. R., Wylie, K. K., Valente, M. S. (2005). Strategic Organizational Change Building Change Capabilities in Your Organization, Palgrave Macmillan. 